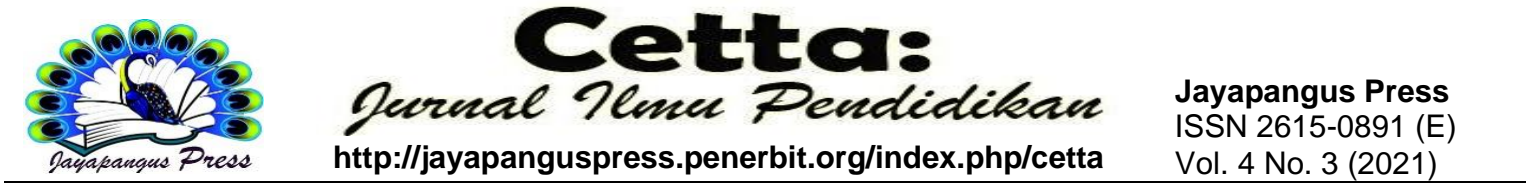

\title{
Studi Dampak Pandemi Covid-19 terhadap Perilaku Belajar, Interaksi Sosial dan Tingkat Spiritual Mahasiswa
}

\section{Wayan Darna}

Universitas Hindu Negeri I Gusti Bagus Sugriwa Denpasar

wayandarna66@gmail.com

\begin{tabular}{l} 
Keywords: \\
\hline Learning \\
Behavior, Social \\
Interaction and \\
Spiritual Level \\
\hline
\end{tabular}

Kata Kunci:

Perilaku Belajar, Interaksi Sosial, Tingkat Spiritual

\begin{abstract}
The study aims to analyze learning behavior, social interaction and spiritual level of UHN I Gusti Bagus Sugriwa students due to the pandemic Covid-19 in order to be able to prepare and do the right things in the era of adapting new habits. This study was quantitative research and used cross-sectional design. Samples that were selected by simple random sampling. Data were collected using online questionnaire. The impact of the covid-19 pandemic for students in college activities is (1)the adjustment of online method, because some areas are constrained by internet signal, quotas, learning platforms, etc. (2) social communication in cyberspace has increased, as a result of not being able to meet face-to-face directly and (3) the spiritual level of students is in the good category. Students have more time to correct themselves to be better, more resilient, and take lessons from what happened
\end{abstract}

Abstrak
Tujuan penelitian ini adalah untuk menganalisis perilaku belajar,
interaksi sosial dan tingkat spiritual mahasiswa akibat pandemi
Covid-19 agar dapat mempersiapkan dan melakukan hal yang
tepat pada era adaptasi kebiasaan baru. Penelitian ini merupakan
riset kuantitatif. Desain yang digunakan adalah crossectional.
Penelitian dilakukan pada mahasiswa UHN I Gusti Bagus
Sugriwa. Sampel dipilih secara simpel random sampling.
Pengumpulan data menggunakan kuesioner online. Dampak
pandemi covid-19 bagi mahasiswa (1) dalam kegiatan
perkuliahan adalah terjadi penyesuaian perkuliahan online dan
ada beberapa kendala yang dihadapi seperti sinyal internet,
kuota, platform pembelajaran, dll (2)komunikasi sosial di dunia
maya meningkat, sebagai akibat tidak bisa tatap muka secara
langsung dan (3) tingkat spiritual mahasiswa dalam kategori
baik. Mahasiswa lebih banyak waktu untuk mengoreksi diri
untuk menjadi lebih baik lagi, lebih tabah, dan mengambil
hikmah dari yang terjadi.




\section{Pendahuluan}

Pandemi global dinyatakan oleh WHO (World Health Organization) pada 11 Maret 2020 akibat wabah covid-19 telah menyebar luas. WHO meminta negara-negara termasuk Indonesia mengambil tindakan yang agresif untuk mencegah dan mengendalikan covid-19. Covid-19 pertama kali muncul di Wuhan, Provinsi Hubei, Tiongkok. Virus ini telah tersebar di seluruh dunia, termasuk Indonesia sejak awal bulan Maret 2020. virus ini yang diduga muncul karena adanya sebuah pasar makanan di Wuhan yang menjual bebagai jenis hewan hidup maupun sudah mati (Ericha, 2020).

Salah satu tindakan pemerintah Indonesia adalah melakukan social distancing selama 14 hari untuk meminimalisir penyebaran virus tersebut. Menurut Center for Disease (CDC) dalam (Kosasih, 2020) social distancing yaitu menjauhi perkumpulan, menghindari pertemuan massal, dan menjaga jarak antar manusia. Pembatasan sosial dan menjaga jarak yang dilakukan untuk mencegah penularan COVID-19 agar tidak menyebar luas di Negara Indonesia. Social Distancing sangat berpengaruh untuk menghambat penyebaran COVID-19.

Suatu penelitian menunjukkan bahwa masyarakat memiliki sikap baik yaitu mematuhi himbauan pemerintah terkait protokol kesehatan, namun lebih dari $80 \%$ orang disibukkan oleh pemikiran tentang covid-19. Informasi tentang covid-19 beredar luas baik di televisi, media masa maupun media sosial sehingga membuat orang selalu memikirkan dan mencemaskan tentang covid-19. Hal tersebut dikawatirkan berdampak pada kesehatan mental seseorang. Penelitian tersebut menunjukkan beberapa dampak yang dialami terkait covid-19 yaitu kesulitan tidur 12,5\%, paranoia tentang infeksi covid$1937,8 \%$ dan merasakan tekanan akibat media sosial sebesar 36,4\% (Roy et al., 2020).

Ada dua dampak bagi keberlangsungan pendidikan yang disebabkan oleh pandemi Covid-19. Pertama adalah dampak jangka pendek, yang dirasakan oleh banyak keluarga di Indonesia baik di kota maupun di desa. Di Indonesia banyak keluarga yang kurang familiar melakukan sekolah di rumah. Bersekolah di rumah bagi keluarga Indonesia adalah kejutan besar khususnya bagi produktivitas orang tua yang biasanya sibuk dengan pekerjaannya di luar rumah. Demikian juga dengan problem psikologis anak-anak peserta didik yang terbiasa belajar bertatap muka langsung dengan guru-guru mereka. Seluruh elemen pendidikan secara kehidupan sosial "terpapar" sakit karena covid-19. Pelaksanaan pengajaran berlangsung dengan cara online. Proses ini berjalan pada skala yang belum pernah terukur dan teruji sebab belum pernah terjadi sebelumnya. 
Kedua adalah dampak jangka panjang. Dampak pendidikan dari sisi waktu jangka panjang adalah aspek keadilan dan peningkatan ketidaksetaraan antar kelompok masyarakat dan antardaerah di Indonesia.

Dampak covid-19 juga dialami oleh mahasiswa. Perkuliahan daring dipilih sebagai solusi dalam kegiatan perkuliahan konvensional yang tidak dapat diterapkan akibat pembatasan sosial. Pembelajaran jarak jauh meminimalisir kerumunan sebagai langkah nyata menerapkan protokol kesehatan dalam rangka pencegahan penularan covid-19 (Firman \& Rahayu, 2020). Namun pada beberapa penelitian, perkuliahan daring membutuhkan penyesuaian sehingga menjadi kendala bagi mahasiswa. Penelitian pada mahasiswa ilmu keolahragaan Unesa, kendala yang dirasakan pada perkuliahan daring meliputi paket kuota data dan sinyal yang minim ditambah dengan teknis perkuliahan yang memberatkan mahasiswa dengan penugasan yang banyak dengan deadline pengerjaan yang pendek (Sulata \& Hakim, 2020). Pandemi covid-19 berdampak banyak hal selain kematian global, yaitu pada sektor ekonomi dan berdampak pada bidang lain termasuk pendidikan.

Permasalahan dalam bidang pendidikan terkait akses informasi teknologi dan media dimana terdapat kesenjangan pada suatu populasi yang memiliki pendapatan tinggi dapat memenuhi akses teknologi dan mengikuti pendidikan secara digital. Pandemi covid-19 membuat aktivitas dibatasi, baik kegiatan perkantoran, perkuliahan atau sekolah maupun aktivitas lainnya. Mahasiswa yang memiliki rutinitas olahraga pun harus terhenti karena pusat kebugaran dan pusat latihan ditutup. Beberapa memilih latihan sendiri di rumah, namun ada pula yang mengalihkan aktivitasnya, dengan tidak latihan, membantu orang tua atau bekerja untuk mencari tambahan uang saku.

Mahasiswa mengalami dampak secara langsung maupun tidak langsung, termasuk dalam hal keuangan. Mahasiswa sebagian tidak dapat mengikuti kuliah online karena tidak memiliki uang untuk membeli kuota internet, karena uang saku berkurang atau tidak ada. Sebagian kesulitan bekerja karena jalan-jalan ditutup atau tempat bekerja mereka tidak beroperasional, sebagian pula merasakan dampak tidak langsung berupa penurunan bahkan berhentinya uang saku karena orang tua mereka tidak lagi bisa bekerja. Keterbatasan uang saku membuat pola makan tidak teratur, makan seadanya. Beberapa interaksi sosial dilakukan (bertemu langsung) tetapi akses jalan banyak ditutup.

Hal yang tidak kalah penting dalam menghadapi pandemi Covid-19 adalah menjaga tingkat spiritualitas. Spiritualitas adalah keyakinan hubungan dengan Yang 
Maha Kuasa dan Maha Pencipta serta tentang kekuatan hidup yang berguna bagi masyarakat dan lingkungan majemuk tanpa kehilangan identitas diri serta aspek besar dalam setap kehidupan manusia dengan dimensi masing-masiang yakni motivasi dan pemberi kekuatan. Individu yang mengalami masalah spiritual dapat menyebabkan kehilangan hubungan dengan Tuhan dan kehidupan yang tidak berarti. Perasaan-perasaan tersebut akan membuat seseorang menjadi stress dan depresi berat sehingga menurunkan kekebalan tubuh yang akan membuat kondisi semakin memburuk.

Penelitian ini perlu dilakukan untuk menganalisis perilaku belajar, interaksi sosial dan tingkat spiritual akibat pandemi covid-19. Urgensi dalam penelitian ini adalah dimana pandemi covid-19 merupakan hal yang baru sehingga perlu dikaji mengenai dampak yang dialami sehingga dapat dirancang upaya mengatasi kesulitan akibat covid-19 sebagai upaya adaptasi kebiasaan baru. Tujuan penelitian ini untuk menganalisis perilaku belajar, interaksi sosial dan tingkat spiritual akibat pandemi agar dapat mempersiapkan dan melakukan hal yang tepat pada era adaptasi kebiasaan baru. Pandemi masih ada namun beberapa aktivitas harus tetap berjalan agar produktivitas tidak terhenti, harapannya penelitian ini memberikan kontribusi dalam perilaku adaptasi kebiasaan baru.

\section{Metode}

Penelitian dilakukan pada bulan Agustus 2020. Subyek yang diteliti adalah mahasiswa UHN I Gusti Bagus Sugriwa. Penelitian ini dilakukan dengan pendekatan kuantitatif. Jenis penelitian adalah deskriptif. Desain yang digunakan menggunakan pendekatan cross sectional. Pengumpulan data menggunakan kuesioner dampak pandemi covid-19 bagi mahasiswa UHN I Gusti Bagus Sugriwa. Kuesioner disusun oleh peneliti berupa pertanyaan terbuka dan tertutup. Jenis pertanyaan berkaitan dengan pengalaman dan pendapat. Keabsahan data berdasarkan obyektivitas berkenaan derajat kesepakatan antar banyak orang. Kuesioner dilakukan uji pada kelompok mahasiswa diperoleh hasil 15 dari 20 pertanyaan dinyatakan valid berdasarkan uji signifikansi koefisien korelasi. Pertanyaan tidak valid tidak digunakan dalam penelitian, sehingga tersisa 15 butir pertanyaan. Nilai koefisien reliabilitas 0,68 sehingga dinyatakan reliabel. Sampel penelitian adalah mahasiswa UHN I Gusti Bagus Sugriwa sebanyak 82 mahasiswa. Teknik pengambilan sampel secara simpel random sampling. Variabel yang akan diukur adalah perubahan pola belajar, interaksi sosial, dan sosial ekonomi mahasiswa. Teknik pengambilan data menggunakan kuesioner online, yang berisi pertanyaan tertutup dan 
terbuka analisis dan model statistik yang digunakan. Kuesioner menggunakan google form. Analisis dilakukan secara kuantitatif, yaitu analisa univariat untuk mengetahui gambaran data yang telah dikumpulkan dengan distribusi frekuensi.

\section{Hasil dan Pembahasan}

Penelitian dilakukan pada mahasiswa UHN I Gusti Bagus Sugriwa diikuti oleh 82 mahasiswa. Mahasiswa sebagian besar berasal dari Provinsi Bali. Pandemi berdampak pada banyak aspek dalam kehidupan sehari-hari. Beberapa orang di antaranya meski mengalami dampak namun mampu beradaptasi, namun beberapa lainnya merasakan dampak yang lebih berat. Partisipan sebanyak $62 \%$ mengalami dampak langsung maupun tidak langsung, dan sebesar 38\% dapat memahami kondisi dan menyesuaikan.

\section{Dampak Pandemi Covid-19 Terhadap Perilaku Belajar}

Perkuliahan dilakukan secara online sesuai Pedoman Umum Penyelenggaraan Pendidikan selama Masa Pandemi Covid-19. Panduan tersebut sesuai dengan Surat Edaran Menteri Pendidikan dan Kebudayaan serta mempertimbangkan edaran Gubernur Bali tentang Protokol Status Tanggap Darurat Bencana Pandemi Covid-19 Lingkungan Pendidikan Provinsi Bali. Perkuliahan full online merupakan hal yang baru sehingga beberapa mahasiswa mengalami kesulitan. Pemanfaatan teknologi itu sendiri pun merupakan hal yang baru sehingga membutuhkan adaptasi, sementara beberapa daerah mengalami kendala jaringan. Strategi belajar online, memberikan kondisi yang berbeda, beberapa merasa kesulitan menangkap materi dan kesulitan belajar. Hasil penelitian menunjukkan bahwa sebanyak $83 \%$ tidak mengalami kendala atau mengalami kendala tetapi sudah teratasi, sedangkan $17 \%$ lainnya mengalami kendala untuk mengikuti perkuliahan online. Kondisi selama perkuliahan online dijelaskan dalam tabel 1.

Tabel 1. Kondisi Perkuliahan Online Selama Masa Pandemi

\begin{tabular}{ccc}
\hline Kondisi Selama Perkuliahan & Jumlah (f) & Persentase (\%) \\
\hline Tidak ada kendala & 68 & 83 \\
\hline Mengalami Kendala & 14 & 17 \\
\hline
\end{tabular}

Beberapa mahasiswa mengatakan materi lebih sulit dipahami dan lebih nyaman tatap muka langsung. Semua mata kuliah diberikan secara daring, memungkinkan pembelajaran mandiri yang lebih banyak sehingga mahasiswa merasa lebih banyak tugas yang harus dikerjakan, lebih banyak di depan laptop atau HP sehingga mata lelah. Biaya 
paket internet yang diperlukan lebih banyak, baik untuk mengikuti kuliah maupun mengerjakan dan mengumpulkan tugas. Sementara mereka yang terdampak secara ekonomi, harus membantu orang tua bekerja sehingga waktu belajar lebih sedikit. Perkuliahan dilakukan secara daring membuat jadwal perkuliahan lebih fleksibel, sehingga ada kalanya dilakukan di luar jadwal perkuliahan.

Pembelajaran online memiliki keterbatasan pada pembelajaran praktik, karena tidak bisa melakukan langsung di lapangan. Selain itu, mereka yang biasanya presentasi di depan kelas dan diskusi tanya jawab tidak bisa dilakukan lagi. Mahasiswa yang merasa tidak ada kendala atau sudah bisa mengatasi kendala (83\%), sebanyak $12 \%$ diantaranya bahkan merasakan menjadi belajar lebih giat. Perkuliahan online memungkinkan pertemuan tatap muka dengan dosen dan teman-teman juga memberikan rasa senang serta membantu memahami materi perkuliahan.

Hal positif lain adalah lebih memanfaatkan teknologi, lebih banyak mengetahui aplikasi yang bisa membantu kuliah online. Keuntungan penggunaan pembelajaran online adalah pembelajaran bersifat mandiri dan interaktivitas yang tinggi, mampu meningkatkan tingkat ingatan, memberikan lebih banyak pengalaman belajar, dengan teks, audio, video dan animasi yang semuanya digunakan untuk menyampaikan informasi, dan juga memberikan kemudahan menyampaikan, memperbarui isi, mengunduh, para mahasiswa juga bisa mengirim email kepada mahasiswa lain, mengirim komentar pada forum diskusi, memakai ruang chat, hingga link videoconference untuk berkomunikasi langsung. Dengan adanya kebijakan ini, bukan hanya aspek intelektual yang mempengaruhi namun ada juga pengaruhnya pada aspek spiritual dan sosial baik secara positif maupun secara negatif. “

Perkuliahan diberikan dengan metode beragam sesuai kontrak perkuliahan. Sebagian besar mahasiswa, sebanyak 74\% mengatakan download dan menggunakan aplikasi baru dalam kegiatan perkuliahan dan kegiatan lain yang mendukung perkuliahan. Beberapa platform yang digunakan adalah google classroom, zoom, google meet, platform dari fakultas setempat, termasuk WhatsApp dan Telegram. Materi praktik disampaikan dengan memberikan panduan kemudian mahasiswa mempraktikkan sehingga seringkali mahasiswa melaporkan kegiatan praktik melalui video. Sebanyak 28\% mahasiswa mengatakan mempelajari keterampilan baru terkait edit video dengan berbagai macam aplikasi. Mahasiswa menjadi lebih menguasai microsoft office (word, excel, power point) dan penggunaan $p d f$. 
Perilaku belajar lain adalah lebih sering membaca jurnal atau buku online, membaca dari situs wikipedia Indonesia, aplikasi membaca gratis seperti ipusnas, duolingo dan quora. Selain itu belajar dari video yang memuat informasi umum dan pengetahuan umum di youtube. Selain kegiatan belajar mahasiswa juga mendapat pengalaman baru yaitu bekerja untuk menambah uang saku. Selama mengikuti perkuliahan daring, sebanyak $32 \%$ mengalami kendala dan $68 \%$ sisanya cukup adaptif, mampu menyesuaikan. Kendala yang dialami dijelaskan pada gambar 1 yaitu jaringan yang kurang memadai, kuota terbatas, materi lebih susah dipahami. Kuliah daring dalam bentuk interaksi langsung seperti zoom dan google meet, terkendala jaringan seringkali suara tidak jelas dan membutuhkan kuota lebih banyak. Metode interaksi tidak langsung memiliki keterbatasan dalam diskusi.
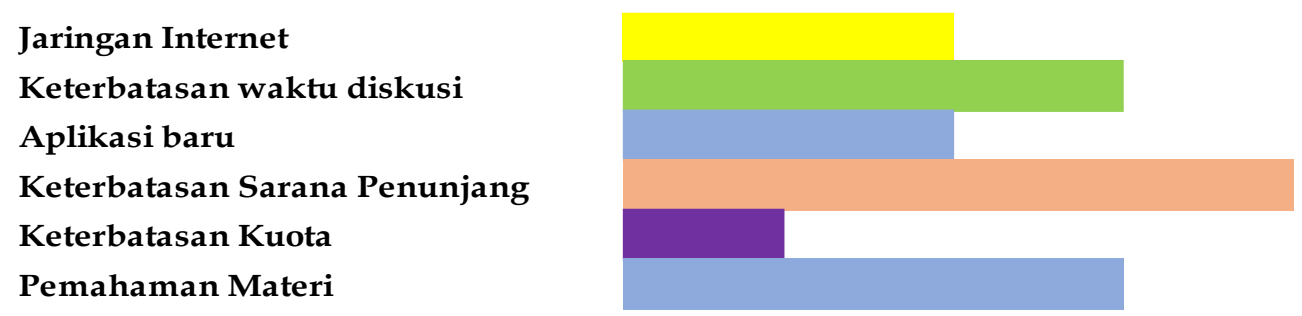

Gambar 1. Kendala Perkuliahan Online

Mahasiswa yang akan mengikuti ujian harus memenuhi protokol kesehatan untuk proses pendaftaran dan ujian seminar, yang pada waktu itu terkendala secara teknis. Kendala juga dialami mahasiswa yang melakukan penelitian. Proposal yang telah disusun memerlukan interaksi langsung, atau pengambilan data di sekolah dan di tempat lain. Status tanggap bencana mengharuskan belajar dari rumah sehingga mahasiswa memiliki kendala dalam pengumpulan data.

\section{Dampak Pandemi Covid-19 terhadap Interaksi Sosial}

Pembatasan sosial memberikan peluang komunikasi dan relasi sosial melalui dunia maya. Hal itu pula yang dialami responden pada penelitian ini. Teknologi komunikasi memiliki peranan dalam menjaga interaksi sosial individu dengan individu maupun dengan kelompok. Komunikasi online meningkat dialami sebanyak $87 \%$ responden, seperti yang tercantum pada gambar 2 . Sebanyak $46 \%$ mengatakan lebih dekat dengan keluarga melalui tatap muka tidak langsung, 72\% masih bertemu keluarga secara tatap muka langsung, 24\% tidak bertemu dengan keluarga, sisanya mengatakan jarang bertemu dan lainnya. 


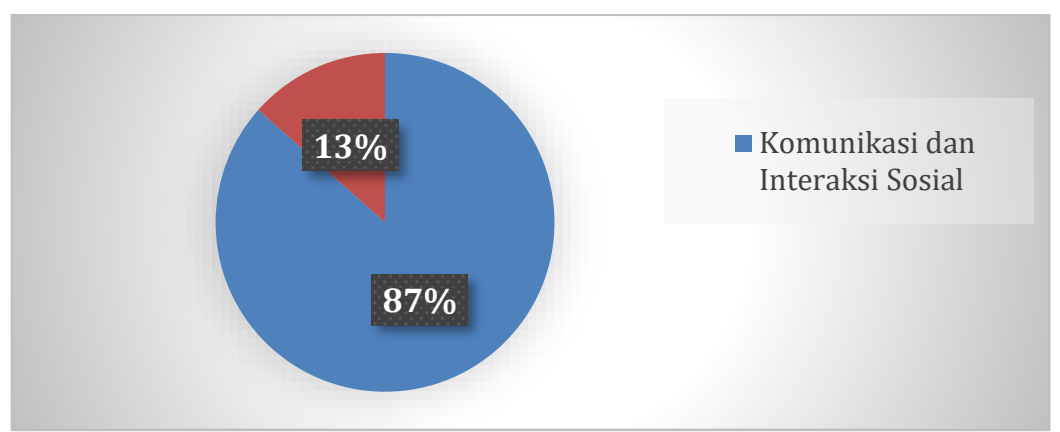

Gambar 2. Perubahan Interaksi Sosial

Interaksi sosial individu dengan individu maupun kelompok juga terjadi pada kegiatan ibadah. Kegiatan persembahyangan juga terdampak karena sebagian besar aktivitas di rumah saja, tempat persembahyangan ditutup. Sebanyak 48,9\% mengatakan lebih sering berdoa agar terhindar dari sakit, namun sebesar 36,5\% mengatakan perilaku ibadah tetap seperti sebelum pandemi dan sisanya tidak menjawab, lebih jarang mengikuti ibadah dan lainnya. Kegiatan ibadah dilakukan di rumah bersama keluarga, beberapa daerah masih menyelenggarakan ibadah dengan menerapkan protokol Kesehatan.

\section{Dampak Pandemi Covid-19 terhadap Tingkat Spiritualitas}

Spiritual bukan hanya terjadi ketika seseorang melakukan perilaku ritual (beribadah), tapi juga ketika melakukan aktivitas lain yang didorong oleh kekuatan supranatural. Spiritual bukan hanya yang berkaitan dengan aktivitas yang tampak dan dapat dilihat mata, tapi juga aktivitas yang tidak tampak dan terjadi dalam hati seseorang, misalnya berdoa.

Dari hasil penelitian ini ditemukan beberapa argumen bahwa (1) sebanyak 15\% mahasiswa menyatakan bahwa dampak pandemi ini membuat mahasiswa belajar online dirumah masing-masing, saat belajar di rumah pun bukan hanya sekedar belajar yang dilakukan bahkan ada kegiatan lain yang dilakukan akhirnya hal itu membuat diri capek ditambah lagi jika ada tugas-tugas yang harus dikerjakan jadinya hal itu membuat kemalasan datang untuk melakukan kegiatan spiritual seperti berdoa, (2) sebanyak 72\% mahasiswa menyatakan keinginan untuk melakukan persembahyangan secara langsung di Pura karena semenjak pandemi ini kegiatan peribadahan dibatasi berbeda dengan suasana sebelum pandemi dan akhirnya merindukan peribadahan secara langsung dimana kita bertemu satu sama lain tanpa ada batasan seperti sedia kala, (3) sebanyak 88\% menyatakan ada dampak buruk dan positif terhadap spiritual dengan adanya Covid 19, 
sisi baiknya adalah lebih banyak waktu untuk mengoreksi diri untuk menjadi lebih baik lagi, lebih tabah, dan mengambil hikmah dari yang terjadi dan (4) sebanyak 7\% mahasiswa menyatakan kepercayaan yang mulai memudar karena mengira bahwa Tuhan tidak mempunyai kuasa untuk menghilangkan Virus ini atau dengan kata lain mengakhiri pandemi ini.

Dari hasil penelitian ini menunjukan beberapa hasil yang sama yaitu sikap yang cukup baik namun sebagian besar merasakan kecemasan, yang dalam penelitian ini terlihat dari perilaku over protektif akibat informasi yang diterima. Beberapa di antaranya mengatakan harus berada di kampung halaman karena orang tua mencemaskan berada di Denpasar yang merupakan zona merah. Hasil penelitian menunjukkan bahwa sebagian besar mahasiswa mengalami kendala perkuliahan, berupa jaringan internet, kuota internet untuk mengikuti aktivitas perkuliahan dan penugasan, pemahaman materi dan lainnya.

Kondisi tersebut serupa dengan penelitian pada Program Studi Ilmu Keolahragaan Universitas Negeri Surabaya bahwa terdapat beberapa kendala perkuliahan daring. Kendala tersebut meliputi paket kuota data dan sinyal yang minim ditambah dengan teknis perkuliahan yang memberatkan mahasiswa dengan penugasan yang banyak dengan deadline pengerjaan yang pendek (Sulata \& Hakim, 2020). Kondisi tersebut sejalan dengan temuan Nicola, Alsafi, Sohrabi, Kerwan, \& Al-jabir (2020) dimana terdapat kesenjangan pada suatu populasi yang memiliki pendapatan tinggi dapat memenuhi akses teknologi dan mengikuti pendidikan secara digital. Kendala lain yang juga ditemui pada penelitian ini adalah pembatasan kegiatan penelitian selain covid-19, sementara proposal yang telah dirancang mahasiswa pada periode sebelumnya bahkan mungkin membutuhkan kontak fisik dan perlu mengabaikan physical distancing sehingga perlu dipertimbangkan metode baru.

Penyebab utama tidak optimalnya penggunaan internet dalam pembelajaran menurut Pujilestari (2020) adalah kurangnya ketersediaan sumber daya manusia, transformasi teknologi, infrastruktur telekomunikasi dan perangkat hukumnya yang mengaturnya. Selain itu masih terdapat kekurangan pada infrastruktur teknologi telekomunikasi, multimedia dan informasi. Akses internet perlu diperluas. Sebagian besar mahasiswa di kampung sehingga banyak yang mengalami kendala jaringan internet. Selaras dengan Firman \& Rahayu (2020) bahwa pembelajaran online memberikan fleksibilitas serta mampu mendorong munculnya kemandirian belajar dan motivasi untuk lebih aktif dalam belajar. Kondisi tersebut juga dialami mahasiswa UHN I Gusti Bagus 
Sugriwa dalam penelitian ini, mereka harus belajar mandiri untuk memahami materi dan memenuhi tugas serta lebih banyak mencari referensi dari jurnal atau buku online, situs online dan aplikasi.

Penelitian Herliandry \& Suban (2020) menuliskan pembelajaran online menjadi solusi efektif untuk mengaktifkan kelas. UHN I Gusti Bagus Sugriwa berlokasi di zona merah, metode kuliah online diharapkan efektif untuk mengurangi resiko penyebaran penularan. Namun evaluasi kegiatan perkuliahan beberapa kondisi belum bisa terlaksana secara sempurna mengingat beberapa lokasi terkendala jaringan. Beberapa solusi dilakukan misalnya dengan memperpanjang rentang waktu pengumpulan tugas, memilih dan menyepakati metode yang lebih luas menjangkau peserta didik. Kendala dalam penerapan pembelajaran online yang dijelaskan (Abidin, Rumansyah, \& Arizona, 2020) di antaranya kuota internet yang terbatas dan masih belum familiarnya tenaga pendidik beserta peserta didik dalam mengaplikasikannya.

Kondisi tersebut memerlukan strategi khusus lebih masif. Salah satu pendekatan pembelajaran adalah pembelajaran berbasis proyek, yang peluang kepada peserta didik untuk mempelajari konsep secara mendalam sekaligus meningkatkan hasil belajarnya. Interaksi dalam pendekatan belajar ini dapat terjadi secara efektif dengan memanfaatkan proses penyelidikan yaitu dengan mengarahkan peserta didik untuk membuat atau mengembangkan produk yang aplikatif dan berkaitan dengan kehidupan sehari-hari. Konsep adaptasi kebiasaan baru memungkinkan pertemuan tatap muka di kelas dengan memperhatikan protokol kesehatan. Ruang belajar dilengkapi dengan fasilitas mencuci tangan, menjaga jarak antar mahasiswa, pemakaian masker dan lainnya. Metode tatap muka diperlukan pada capaian pembelajaran tertentu yang lebih efektif jika dilakukan secara tatap muka sedangkan capaian pembelajaran lain tetap dilakukan secara online. Model pembelajaran tersebut adalah pembelajaran berbasis blended learning (PBBL). PBBL merupakan pembelajaran yang mengombinasikan keunggulan belajar melalui tiga sumber belajar utama, yaitu tatap muka, offline, dan online (Dwiyogo, 2018).

Alternatif metode pembelajaran serupa dengan model pembelajaran yang diungkapkan oleh Jayul \& Irwanto (2020) dimana metode daring sebagai alternatif, namun untuk memfasilitasi metode pembelajaran praktik menggunakan metode dengan aplikasi video. Prinsip pembelajaran berdasarkan tiga aspek penilaian dalam pendidikan yaitu kognitif, afektif, dan psikomotor. Mahasiswa diminta melakukan praktik secara mandiri di rumah masing-masing kemudian hasil belajar disampaikan kepada dosen 
dalam bentuk video, baik secara offline maupun live. Penelitian dilakukan pada masa pembatasan sosial berskala besar. Selain aktivitas kampus, aktivitas sosial dan perekonomian juga terdapat pembatasan. Perkuliahan praktik, basket misalnya yang diungkapkan responden, pembelajaran dilakukan secara mandiri di rumah, kemudian hasil kegiatan dilaporkan kepada dosen. Kegiatan yang harus dilakukan secara beregu, dilakukan bersama dengan anggota keluarga atau orang lain yang satu rumah/lingkungan.

Tipe pembelajaran tersebut serupa dengan rancangan pembelajaran model distance learning sebagai potensi pembelajaran pada anak sekolah dan collaborative approach dengan orang tua siswa melalui lembar pengamatan aktivitas belajar (Herlina \& Suherman, 2020). Komunikasi sosial dalam dunia maya meningkat selama masa pandemi. Mereka mendapat informasi terkait status perkembangan covid-19, upaya pencegahan serta kegiatan sosial terkait covid-19. Hal ini sesuai (Sampurno, Kusumandyoko, \& Islam, 2020) bahwa media dan sumber pengetahuan selalu berkembang. Media sosial memiliki peran dalam edukasi kesehatan masyarakat untuk mempercepat penyebaran informasi terkait covid-19. Pengembangan sumber media statis berupa buku diaplikasikan dalam bentuk yang dinamis dan virtual, yang dalam penelitian ini beberapa mahasiswa memanfaatkan referensi belajar secara virtual. Informasi melalui media sosial dan media online lain perlu dilakukan batasan dan penyaringan. Hasil penelitian di China diketahui bahwa orang-orang yang lebih muda berada pada risiko tinggi menampilkan masalah psikologis. Masalah yang dilaporkan yaitu gangguan kecemasan, gejala depresi, dan kurang tidur. Orang yang lebih muda melaporkan prevalensi gangguan kecemasan dan gejala depresi yang lebih tinggi daripada orang tua (Huang \& Zhao, 2020). Hal tersebut perlu menjadi perhatian karena mahasiswa sebagai anggota masyarakat sebagai kelompok orang lebih muda sedangkan sebagian kecil mahasiswa mengatakan stress karena banyak tugas dan kurang memahami materi yang diberikan.

Kesulitan memahami materi perkuliahan serupa dengan penelitian pada Stikes Rajekwesi Bojonegoro, dimana 54.5\% sulit memahami materi perkuliahan, kreativitas mahasiswa 50\%, pelaksanaan tugas oleh mahasiswa 56.5\% sulit dan lambat, dan $41 \%$ mahasiswa kurang aktif selama perkuliahan (Rahmawati \& Putri, 2020). Kreativitas ditemukan dari keterampilan diluar kompetensi kuliah berupa mengenal aplikasi baru, editing video, dan lainnya. Pelaksanaan tugas sulit dan lambat serta kurang aktif karena terkendala jaringan dan banyaknya tugas, 
Pelaksanaan pembatasan sosial lebih terkendali karena perkuliahan dilakukan secara online, sehingga mencegah keramaian atau perkumpulan mahasiswa. Hal tersebut juga disebutkan oleh Firman \& Rahayu (2020) pada studi yang dilakukan pada mahasiswa Pendidikan Biologi Universitas Sulawesi Barat. Perilaku physical distancing pada mahasiswa perempuan lebih baik. Sementara upaya menghambat penularan virus membutuhkan perubahan perilaku yang signifikan, tidak sekedar mematuhi himbauan pemerintah tetapi dari kesadaran.

Berbagai aspek konteks sosial dan budaya mempengaruhi tingkat dan kecepatan perubahan perilaku. Aspek konteks sosial dapat membantu pembuat keputusan mengidentifikasi faktor risiko dan secara efektif melakukan intervensi. Keterlibatan tokoh agama, tokoh masyarakat dinilai efektif dalam menyebarluaskan pesan kesehatan. Pembatasan sosial atau jaga jarak fisik juga memberikan kontribusi dalam pencegahan penularan covid-19 (Bavel et al., 2020).

Terkait dengan tingkat spiritualitas adalah suatu hal yang sangat penting untuk setiap individu. Menurut (Hupcey, 2013) dalam penelitiannya terhadap 45 pasien kritis di ruangan Intensive Care Unit yang telah dirawat selama tiga hari menunjukkan bahwa pasien-pasien ini mengalami cemas, rasa takut akan penyakitnya, kehilangan kontrol dan harapan hidup. Kondisi ini menyebabkan krisis dan perubahan yang merupakan salah satu faktor yang mempengaruhi spiritualitas seseorang. Spiritualitas adalah keyakinan hubungan dengan Yang Maha Kuasa dan maha pencipta serta tentang kekuatan hidup yang berguna bagi masyarakat dan lingkungan majemuk tanpa kehilangan identitas diri serta aspek besar dalam setap kehidupan manusia dengan dimensi masing-masiang yakni motivasi dan pemberi kekuatan.

Individu yang mengalami masalah spiritual dapat menyebabkan individu kehilangan hubungan dengan Tuhan dan kehidupan yang tidak berarti. Perasaan-perasaan tersebut akan membuat seseorang menjadi stress dan depresi berat sehingga menurunkan kekebalan tubuh yang akan membuat kondisi semakin memburuk

\section{Kesimpulan}

Pandemi memberikan dampak bagi mahasiswa UHN I Gusti Bagus Sugriwa baik dalam perilaku belajar, interaksi sosial maupun tingkat spiritual. Dampak perilaku belajar adalah penyesuaian menggunakan teknologi karena kuliah dilakukan dengan metode online, namun secara teknis terdapat kendala sinyal dan belum optimal untuk 
pembelajaran praktik. Dampak interaksi sosial berupa perilaku over protektif, lebih mudah menaruh curiga ketika ada orang lain yang tidak dalam kondisi sehat. Tingkat Spiritual mahasiswa masih sangat kuat dan sebagian besar mahasiswa dapat mengambil hikmah positif dari Pandemi Covid-19 yang terjadi saat ini. Rekomendasi terkait kegiatan perkuliahan untuk dipertimbangkan metode yang dapat dijangkau secara luas. Strategi perkuliahan perlu dipertimbangkan pada metode yang fokus pada pencapaian hasil belajar. Metode blended learning dipertimbangkan, mengingat metode ceramah meski bukan metode terbaik tetapi tetap diperlukan dan dirindukan selama masa perkuliahan online.

\section{Daftar Pustaka}

Abidin, Z., Rumansyah, \& Arizona, K. (2020). Pembelajaran Online Berbasis Proyek Salah Satu Solusi Kegiatan Belajar Mengajar Di Tengah Pandemi Covid-19. Jurnal Ilmiah Profesi Pendidikan, 5(1), 64-70.

Agustini, A. (2019). Promosi Kesehatan. Yogyakarta: Deepublish Publisher.

Bavel, J. J. Van, Baicker, K., Boggio, P. S., Capraro, V., Cichocka, A., Cikara, M. Weeden, K. A. (2020). Using Social and Behavioural Science to Support COVID-19 Pandemic Response.Nature Human Behaviour, 4(May), 460-471. https://doi.org/10.1038/s41562-020-0884-Z

Dwiyogo, W. D. (2018). Pembelajaran Berbasis Blended Learning. Depok: PT. Raja Grafindo Persada.

Ericha Windhiyana Pratiwi, (2020), Dampak Covid-19 terhadap Kegiatan Pembelajaran Online di Sebuah Perguruan Tinggi Kristen di Indonesia. Perspektif Ilmu Pendidikan. http://doi.org/10.21009/PIP.341.1 Volume 34 Issue 1 April 2020 pISSN: 1411-5255 e-ISSN: 2581-2297

Firman, F., \& Rahayu, S. (2020). Pembelajaran Online di Tengah Pandemi Covid-19. Indonesian Journal of Educational Science (IJES), 2(2), 81-89. https://doi.org/10.31605/ijes.v2i2.659

Herliandry, L. D., \& Suban, M. E. (2020). Jurnal Teknologi Pendidikan Pembelajaran Pada Masa Pandemi Covid-19, 22(1), 65-70.

Herlina, \& Suherman, M. (2020). Potensi Pembelajaran Pendidikan Jasmani Olahraga dan Kesehatan (PJOK) di Tengah Pandemi Corona Virus Disease (Covid)-19 di Sekolah Dasar. Tadulako Journal Sport Sciences and Physical Education. 
Huang, Y., \& Zhao, N. (2020). Chinese Mental Health Burden during the COVID19Ppandemic. Asian Journal of Psychiatry, 51(March), 102052. https://doi.org/10.1016/j.ajp.2020.102052

Jayul, A., \& Irwanto, E. (2020). Model Pembelajaran Daring Sebagai Alternatif Proses Kegiatan Belajar Pendidikan Jasmani di Tengah Pandemi Covid-19. Jurnal Pendidikan Kesehatan Rekreasi, 6(2), 190-199. https://doi.org/6, No. 2, Hal. 190 - 199, Juni 2020.

Irfan Arif Darma. (2020). Dampak Covid-19 terhadap Perkembangan Pembelajaran.

Jurnal AgriWidya. Vol, 1 No.3. Pusat Pelatihan Manajemen Dan Kepemimpinan Pertanian, Bogor

Nicola, M., Alsafi, Z., Sohrabi, C., Kerwan, A., \& Al-jabir, A. (2020). Since January 2020 Elsevier has created a COVID-19 resource centre with free information in English and Mandarin on the novel coronavirus COVID- 19 . The COVID-19 resource centre is hosted on Elsevier Connect, the company' s public news and information, (January).

Pujilestari, Y. (2020). Dampak Positif Pembelajaran Online Dalam Sistem Pendidikan Indonesia Pasca Pandemi Covid-19. Adalah, 4(1), 49-56. Retrieved from http://journal.uinjkt.ac.id/index.php/adalah/article/view/15394/7199

Rahmawati, \& Putri, E. M. (2020). Learning From Home dalam Perspektif Persepsi Mahasiswa Era Pandemi Covid-19. Prosiding Seminar Nasional Hardiknas, 17$24,17-24$.

Roy, D., Tripathy, S., Kar, S. K., Sharma, N., Verma, S. K., \& Kaushal, V. (2020). Study of knowledge, attitude, anxiety \& perceived mental healthcare need in Indian population during COVID-19 pandemic. Asian Journal of Psychiatry, 51(April), 102083. https://doi.org/10.1016/j.ajp.2020.102083

Sampurno, M. B. T., Kusumandyoko, T. C., \& Islam, M. A. (2020). Budaya Media Sosial, Edukasi Masyarakat, dan Pandemi COVID-19. SALAM: Jurnal Sosial Dan Budaya Syar-I, 7(5). https://doi.org/10.15408/sjsbs.v7i5.15210

Sulata, M. A., \& Hakim, A. A. (2020). Gambaran Perkuliahan Daring Mahasiswa Ilmu Keolahragaan Unesa di Masa Pandemi Covid-19. Jurnal Kesehatan Olahraga, 08(03), 147-156. 